Univerzitet u Beogradu
Poljoprivredni fakultet
Institut za poljoprivrednu tehniku
Naučni časopis
POLJOPRIVREDNA TEHNIKA
Godina XLIII
Broj 1, 2018.
Strane: $39-51$
AGRICULThity of Belgrade

\title{
THIN LAYER MODELING AND DETERMINATION OF THERMODYNAMIC PROPERTIES OF TOMATO SLICES DURING HOT AIR DRYING
}

\author{
Nnaemeka Nwakuba ${ }^{1} *$, Osita Chukwuezie ${ }^{2}$, Sabbas Asoegwu $^{3}$, \\ Godfrey Nwandikom ${ }^{3}$, Ngozi Okereke ${ }^{3}$ \\ ${ }^{I}$ Agricultural and Bioresources Engineering Department, Michael Okpara University of \\ Agriculture, Umudike, P.M.B. 7267 Umuahia, Abia State, Nigeria. \\ ${ }^{2}$ Agricultural and Bio-Environmental Engineering Department, Imo State Polytechnic, \\ Umuagwo, P.M.B. 1472, Imo State, Nigeria. \\ ${ }^{3}$ Agricultural and Bioresources Engineering Department, Federal University of Technology, \\ P.M.B. 1526 Owerri, Imo State, Nigeria.
}

\begin{abstract}
The drying kinetics and determination of thermodynamic properties of sliced tomato samples during hot air drying in a hybrid solar-electric crop dryer were presented. One kilogram batch of freshly harvested tomato samples were sliced to $10 \mathrm{~mm}$ thickness and dried at varying air velocities $\left(1.0,1.5\right.$ and $\left.2.0 \mathrm{~ms}^{-1}\right)$ and temperatures $\left(50,55,60,65\right.$, and $\left.70^{\circ} \mathrm{C}\right)$ using the hybrid mode. In order to choose the best drying model, eight thin-layer mathematical models were fitted to the experimental data. The high values of coefficient of determination, $\mathrm{R}^{2}$ and the low values of reduced sum of squares error (SSE) and root mean square error (RMSE) indicated that the Midilli et al. model adequately described the drying process of tomato slices, with its highest $\mathrm{R}^{2}(0.9999)$, lowest $\operatorname{SSE}(0.1136)$ and lowest value of $\operatorname{RMSE}(0.0212)$ at $70^{\circ} \mathrm{C}$ temperature and $2.0 \mathrm{~ms}^{-1}$ air velocity. Arrhenius model was used to represent the drying constant as a function of temperature. The effective moisture diffusivity increased with increase in temperature and air velocity; with the highest value obtained at air velocity of $2.0 \mathrm{~ms}^{-1}$ and temperature of $70^{\circ} \mathrm{C}$, whereas it was lowest at air velocity of $1.0 \mathrm{~ms}^{-1}$ and temperature of $50^{\circ} \mathrm{C}$. The mean activation energy required to dry $1 \mathrm{~kg}$ batch of $10 \mathrm{~mm}$ sliced tomato samples was 39.34 $\mathrm{kJmol}^{-1}$. Enthalpy and Gibbs free energy values were found to decrease with increasing drying temperature as well as the entropy which also exothermically decreased with temperature. Recommendations for further studies were stated.
\end{abstract}

Keywords: Thermodynamic properties, drying kinetics, tomato slices, water desorption, activation energy.

\section{INTRODUCTION}

Tomato (Lycopersicon esculentum L.) is a perishable and seasonal crop generally grown and widely eaten in most countries including Nigeria. It is one of the valuable fruit vegetables which is economically rated to be the second most important vegetable crop after potato [1, 2]. In developing countries such as Nigeria, tomato is a seasonal product, characterized by being in good quality, rich in vitamins and minerals, high moisture (usually above $90 \%$ wet basis),

${ }^{1 *}$ Corresponding author: Email : ${ }^{*}$ E-mail: nrnwakuba@gmail.com 
low fats contents especially at harvest, excessive and cheap in their seasons and scarce, costly and in bad quality during out of seasons [3, 4]. In order to make it available on the market as long as possible after harvest, the products are most often subjected to the drying process.

Its drying is a highly energy intensive operation as a result of the relatively high moisture content at harvest; and for this reason, considerable amounts of energy is required to heat the drying air so as to bring down the high moisture content to a safe storage level (usually $5-15 \%$ w.b.) at a temperature range of $35-65^{\circ} \mathrm{C}[3,4]$.

In order to analyze the drying behaviour of an agricultural product during drying process, the study of its kinetics in thin layers is essential $[5,6,7,8]$. Mathematical modeling involves predicting and simulating drying behaviour of certain parameters and processes in a unified manner regardless of the control mechanism, through empirical and phenomenological models $[9,10]$. Several mathematical models such as the Midilli et al. model, Page model, Newton model, Fick's-diffusion model, Logarithmic model, Henderson and Pabis model etc. have been used to describe the thin layer drying process of agricultural products. These models which describe the characteristics of a particular product being dried are used to estimate the drying time of several products and also to generalize drying curves needed for dryer design and process optimization. The study of thermodynamic properties in the drying process of agricultural products aims to proffer solutions to problems related to stability and optimization of process conditions $[10,11]$. It is necessary for optimal designing and dimensioning of crop dryers and other devices in various processes of preservation of product quality as well as in the proper understanding and provision of information on energy exchanges between one state of equilibrium to the other $[10,12]$. Given the above, this study is circumscribed to model the drying kinetics and determine the thermodynamic properties of tomato slices at varying drying temperatures.

\section{MATERIAL AND METHODS}

\section{Theoretical principles}

The plot of moisture ratio with drying time obtained from the experimental data was used to represent the drying kinetics of tomato slices; since the initial value for moisture ratio is unity for each of the experiments, the moisture ratio curve will explain the drying behaviour better than that of moisture content curve [13]. Therefore, the moisture ratio, MR was calculated from Equation (1a) as [14]:

$\mathrm{MR}=\frac{\mathrm{M}_{\mathrm{t}}-\mathrm{M}_{\mathrm{e}}}{\mathrm{M}_{\mathrm{o}}-\mathrm{M}_{\mathrm{e}}}=\mathrm{e}^{-\mathrm{kt}}$

Where: $\mathrm{M}_{\mathrm{t}}=$ Moisture content at any time, $\mathrm{t}\left(\% \mathrm{db}\right.$.); $\mathrm{M}_{\mathrm{e}}=$ equilibrium moisture content $(\% \mathrm{db}$.); and $\mathrm{M}_{\mathrm{o}}=$ initial moisture content $\left(\% \mathrm{db}\right.$.), $\mathrm{t}=$ drying time (mins.), $\mathrm{k}=$ drying constant $\left(\min ^{-1}\right)$.

The values of $\mathrm{M}_{\mathrm{e}}$ are relatively small when compared to $\mathrm{M}_{t}$ and $\mathrm{M}_{\mathrm{o}}$, and thus had negligible error $[15,16,17]$, therefore the moisture ratio was calculated as Equation (1b):

$\mathrm{MR}=\frac{\mathrm{M}_{\mathrm{t}}}{\mathrm{M}_{\mathrm{o}}}$

The drying rate, DR was obtained as expressed in Equation (2) [1]:

$D R=\frac{M_{t+d t}-M_{t}}{M_{0}-M_{e}}$

Where: $\mathrm{M}_{\mathrm{t}+\mathrm{dt}}=$ moisture content (\%wet basis, wb) at time $\mathrm{t}+\mathrm{dt} ; \mathrm{M}_{\mathrm{t}}=$ Moisture content at time, $\mathrm{t}$ $(\% \mathrm{wb}) ; \mathrm{t}=$ drying time (mins.).

The drying curves were fitted to eight commonly known thin-layer drying models as shown in Table 1. The best of fit was obtained by using three statistical parameters: coefficient of determination $\left(\mathrm{R}^{2}\right)$, reduced sum of squares errors $\left(\chi^{2}\right)$, and root mean square error (RMSE) expressed as Equations (3) - (5) [5-10, 13, 15]: 


$$
\begin{aligned}
& \mathrm{R}^{2}=1-\left[\frac{\sum_{\mathrm{i}=1}^{\mathrm{N}}\left(\mathrm{MR}_{\text {pre }}-\mathrm{MR}_{\text {exp.i }}\right)^{2}}{\sum_{\mathrm{i}=1}^{\mathrm{N}}\left(M R_{\text {pre }}-\mathrm{MR}_{\text {expi }}\right)^{2}}\right] \\
& \chi^{2}=\sum_{\mathrm{i}=1}^{\mathrm{n}} \frac{\left(\mathrm{MR}_{\text {exp. } \mathrm{i}}-\mathrm{MR}_{\text {pre }, \mathrm{i}}\right)^{2}}{\mathrm{~N}-\mathrm{m}} \\
& \text { RMSE }=\sqrt{\frac{\sum_{\mathrm{i}=1}^{\mathrm{N}}\left(\mathrm{MR}_{\text {pre. }}-\mathrm{MR}_{\text {exp }, \mathrm{i}}\right)^{2}}{\mathrm{~N}}}
\end{aligned}
$$

Where: $\mathrm{MR}_{\text {exp. } \mathrm{i}}=$ the ith experimental moisture ratio; $\mathrm{MR}_{\text {pred.i }}=$ the ith predicted moisture ratio; $\mathrm{N}$ $=$ number of observation; $\mathrm{m}=$ number of constants in the drying model; $\mathrm{MR}_{\text {pre }}=$ mean of

\begin{tabular}{|c|c|c|c|}
\hline $\begin{array}{l}\text { Model } \\
\text { No. }\end{array}$ & Model name & Model equation & References \\
\hline 1 & Lewis & $M R=e^{(-k t)}$ & $\begin{array}{l}\text { Zarein et al., 2013; Darvishi, } \\
2012\end{array}$ \\
\hline 2 & Page & $M R=e^{\left(-k t^{n}\right)}$ & $\begin{array}{c}\text { Zarein et al., 2013; Darvishi, } \\
2012\end{array}$ \\
\hline 3 & Henderson and Pabis & $M R=a e^{(-k t)}$ & $\begin{array}{c}\text { Zarein et al., 2013, Darvishi, } \\
2012 .\end{array}$ \\
\hline 4 & $\begin{array}{l}\text { Modified Henderson } \\
\text { and Pabis }\end{array}$ & $\begin{aligned} M R=a e^{(-k t)}+b e^{(-g t)} & \\
& +c\left(e^{-h t}\right)\end{aligned}$ & $\begin{array}{c}\text { Zarein et al., 2013; Sahari and } \\
\text { Driscoll, } 3013\end{array}$ \\
\hline 5 & Logarithmic & $M R=\operatorname{aexp}(-k t)+c$ & Zarein et al., 2013 \\
\hline 6 & Two-term & $M R=a e^{\left(-k_{0 t}\right)}+b e^{\left(-k_{1} t\right)}$ & Sahari and Driscoll, 2013 \\
\hline 7 & Verma et al. & $M R=a e^{(-k t)}+(1-a) e^{(-g t)}$ & $\begin{array}{c}\text { Karathanos, 1999; Darvishi, } \\
2012 .\end{array}$ \\
\hline 8 & Midilli et al. & $M R=a e^{\left(-k t^{n}\right)}+b t$ & $\begin{array}{l}\text { Zarein et al., 2013, Darvishi, } \\
2012 .\end{array}$ \\
\hline
\end{tabular}
predicted moisture ratio.

Table 1. Thin-layer drying models.

The effective moisture diffusivity $\left(D_{\mathrm{e}}\right)$ of food materials characterizes their intrinsic property of mass and moisture transport including molecular diffusion, vapour diffusion, hydrodynamic flow and other mechanisms $[2,18]$. Moisture transfer (water transport) during drying agricultural crops takes place through molecular diffusion, and was described using the solution term of the simplified Fick's second law of diffusion expressed in Equations (6a) and (6b) as [5, 6, 19]:

$$
\begin{aligned}
& \mathrm{MR}=\frac{\mathrm{M}_{\mathrm{t}}-\mathrm{M}_{\mathrm{e}}}{\mathrm{M}_{\mathrm{o}}-\mathrm{M}_{\mathrm{e}}}=\frac{8}{\pi} e^{\left(\frac{-\pi^{2} \mathrm{D}_{\mathrm{e}} \mathrm{t}}{\mathrm{L}^{2}}\right)} \\
& \ln (M R)=\ln \frac{8}{\pi}-\frac{\pi^{2} \mathrm{D}_{\mathrm{e}} \mathrm{t}}{\mathrm{L}^{2}}
\end{aligned}
$$

Where: $\mathrm{MR}=$ moisture ratio; $\mathrm{D}_{\mathrm{e}}=$ effective moisture diffusivity $\left(\mathrm{m}^{2} \mathrm{~s}^{-1}\right) ; \mathrm{L}=$ half thickness of the sliced tomato samples $(\mathrm{mm}) ; \mathrm{t}=$ drying time (mins).

The $\mathrm{D}_{\mathrm{e}}$ was calculated, using the method of slopes as described by $[5,6,19,20]$. A straight line was obtained when the logarithm of moisture ratio (ln MR) was plotted against drying time (t) for different temperatures and air velocities at constant slice thickness. The slope (coefficient $\left.\mathrm{k}_{1}\right)$ of the regression line is related to the effective diffusion coefficient $\left(\mathrm{D}_{\mathrm{e}}\right)$ of sliced tomato samples to be determined by substitution into Equation (7) as [19]:

$$
\mathrm{k}_{1}=\frac{\pi^{2} \mathrm{D}_{\mathrm{e}}}{4 \mathrm{~L}^{2}}
$$

The activation energy $\left(\mathrm{E}_{\mathrm{a}}\right)$ was calculated by applying the drying constant $\left(\mathrm{k}_{\mathrm{d}}\right)$ of the best fitted model to the Arrhenius as expressed in Equation (8) [1, 19]: 
$K_{d}=A_{o} e^{\left(-\frac{E_{a}}{R g T_{a}}\right)}$

The plots of the logarithm of the drying constant $\left(\ln \mathrm{K}_{\mathrm{d}}\right)$ against the reciprocal of the absolute drying temperature $\left(\mathrm{T}_{\mathrm{a}}^{-1}\right)$ gave a linear function expressed as Equation $(9)[6,19]$ :

$$
\ln \mathrm{K}_{\mathrm{d}}=\ln \mathrm{A}_{\mathrm{o}}-\frac{\mathrm{E}_{\mathrm{a}}}{\mathrm{R}_{g} \mathrm{~T}_{\mathrm{a}}}
$$

Where: $\mathrm{K}_{\mathrm{d}}=$ drying constant $=$ effective moisture diffusion coefficient $\left(\mathrm{m}^{2} \mathrm{~s}^{-1}\right) ; \mathrm{A}_{\mathrm{o}}=$ preexponential factor $\left(\mathrm{m}^{2} \mathrm{~s}^{-1}\right) ; \mathrm{E}_{\mathrm{a}}=$ activation energy of diffusion of water $\left(\mathrm{kJmol}^{-1}\right) ; \mathrm{R}_{\mathrm{g}}=$ gas constant $\left(8.3143 \mathrm{kJmol}^{-10} \mathrm{~K}\right) ; \mathrm{T}_{\mathrm{a}}=$ absolute temperature $\left({ }^{\circ} \mathrm{K}\right)$.

Substituting the slope of the linear function, $\mathrm{k}_{2}=\frac{\mathrm{E}_{\mathrm{a}}}{\mathrm{R}_{\mathrm{g}}}$ into Equation (9) yields the activation of the slice tomato samples expressed as Equation (10):

$\mathrm{E}_{\mathrm{a}}=\mathrm{k}_{2} \cdot \mathrm{R}_{\mathrm{g}}$

The coefficient of determination $\left(\mathrm{R}^{2}\right)$ of the model equation was obtained by fitting Equation (9) into the experimental data using linear regression (Minitab version 17). The thermodynamic properties of the drying process of tomato slice in a hybrid solar-electric crop dryer were determined through method described by $[10,11]$ expressed as Equations (11) to (13):

$\Delta \mathrm{H}=\mathrm{E}_{\mathrm{a}}-\mathrm{RT}_{a}$
$\Delta \mathrm{S}=\mathrm{R}\left(\ln \mathrm{A}_{\mathrm{o}}-\ln \frac{\mathrm{K}_{\mathrm{B}}}{\mathrm{h}_{\mathrm{p}}}-\ln \mathrm{T}_{a}\right)$
$\Delta \mathrm{G}=\Delta \mathrm{H}-\mathrm{T}_{a} \Delta \mathrm{S}$

Where: $\Delta \mathrm{H}=$ enthalpy variation $\left(\mathrm{Jmol}^{-1}\right) ; \Delta \mathrm{S}=$ entropy variation $\left(\mathrm{Jmol}^{-1} \mathrm{~K}^{-1}\right) ; \Delta \mathrm{G}=$ Gibbs free energy variation $\left(\mathrm{Jmol}^{-1}\right) ; \mathrm{K}_{\mathrm{B}}=$ Boltsmann constant $\left(1.38 \times 10^{-34} \mathrm{Js}^{-1}\right) ; \mathrm{h}_{\mathrm{p}}=$ Planck constant $\left(6.626 \times 10^{-34} \mathrm{Js}^{-1}\right) ; \mathrm{T}_{\mathrm{a}}=$ absolute temperature $\left({ }^{0} \mathrm{~K}\right)$.

\section{Experimental procedure}

Drying experiment was performed using a hybrid solar-electric convective dryer (Figure 1) designed and developed in the Engineering Workshop of Federal University of Technology, Owerri, Nigeria. A local variety of fresh tomato samples (Gboko Spp.) were procured from a rural market in Owerri, Imo State of Nigeria. The samples were washed and sliced into $10 \mathrm{~mm}$ thickness size using a sharp stainless steel knife and a vernier caliper with the direction of cutting perpendicular to the vertical axis of the tomato samples. The dryer heating unit $(1500 \mathrm{~W})$ was switched on, the required air flow and temperature were initiated by the 4 x 4 matrix keypad of the control unit. The drying chamber (with dimensions: $40 \mathrm{~cm} \mathrm{x} 40 \mathrm{~cm}$ x $50 \mathrm{~cm}$ ) was allowed to maintain steady-state condition. When the optimum preset drying temperature was attained, the arduino microprocessor automatically switches off the heating unit, and turns it on again when the drying chamber temperature falls one degree below the preset temperature. The dryer was programmed to operate at five different temperature thresholds of $50,55,60,65$ and $70^{\circ} \mathrm{C}$, and at three varying air velocities $\left(1.0,1.5\right.$ and $\left.2.0 \mathrm{~ms}^{-1}\right)$. 

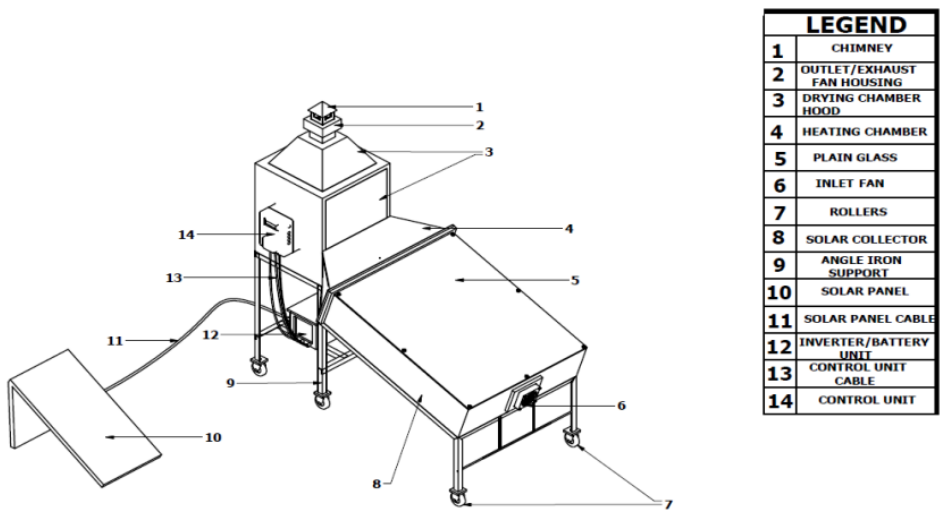

Figure 1. Isometric view of the hybrid drying system.

The initial mass of the $1 \mathrm{~kg}$ batch sliced samples was measured by a digital weighing balance (0.01 g, Camry instruments, China) and recorded, and placed on the drying racks in such a way that the drying air flows axially into the sample matrix (for faster drying). The initial moisture content of the samples was measured by drying $20 \mathrm{~g}$ of representative sliced sample in an oven dryer set at $105^{\circ} \mathrm{C}$ for 24 hours $[8,21,22]$. At every 30 minutes time interval, the control unit of the dryer system (consisting of arduino microprocessor) measures, records and displays on the screen, sample weight loss as well as the drying temperatures and relative humidities of the drying racks, chimney, solar collector, and ambient environment. The difference between the initial dried mass and the 30-minutes interval measured masses were used to calculate the moisture content at any time, $t$ as well as the percentage weight loss for each dried batch. The weight losses were recorded by the use of a weight sensor attached to the weighing balance (with a precision of $0.01 \mathrm{~g}$ ) in the drying chamber. The experiment was repeated for varying sample thicknesses, temperatures and air velocities for a batch of $1000 \mathrm{~g}$. Drying was stopped when variation in the mass of tomato samples on the drying racks remained approximately constant, thus hygroscopic equilibrium was achieved. At this point moisture content decreased from $94.7 \%$ to $12.5 \%$ (w.b.).

\section{RESULTS AND DISCUSSION}

\section{Modeling of drying curves}

The kinetics of water desorption in tomato slices was investigated using the moisture content data (for 50, 55, 60, 65 and $70^{\circ} \mathrm{C}$ temperatures; $1.0,1.5$, and $2.0 \mathrm{~ms}^{-1}$ air velocities; and constant slice thickness of $10 \mathrm{~mm}$ ) converted to moisture ratio using Equation (1b) and then fitted to the eight drying models (Table 1). Amongst the evaluated models, Midilli model showed the best fit to the experimental data of moisture ratio for all air velocity and temperature levels, having the highest mean values of $\mathrm{R}^{2}$ of 0.9996 and lowest mean values of $\chi^{2}(0.1814)$ and $(0.00298)$ RMSE. The Midilli model had the highest value of $\mathrm{R}^{2}$, and lowest values for $\chi^{2}$ and RMSE at $2.0 \mathrm{~ms}^{-1}$ air velocity as shown in Table 2 . At all temperature levels, the values obtained with the Midilli model satisfied the criterion for goodness of fit: highest value of $\mathrm{R}^{2}(0.9999)$, lowest value of $\chi^{2}=0.1136$, and lowest value of RMSE $=0.0212$ at $70^{\circ} \mathrm{C}$ temperature and $2.0 \mathrm{~ms}^{-1}$ air velocity. The best fitted drying model describing the drying behaviour of sliced tomato samples (at air velocity of $2.0 \mathrm{~ms}^{-1}$ and temperature of $70^{\circ} \mathrm{C}$ ) in a hybrid solar-electric dryer is therefore expressed as Equation (14):

$\mathrm{MR}_{\text {tomato }}=4.926 \mathrm{e}^{\left(-0.8041 \mathrm{t}^{1.322}\right)}+0.007 \mathrm{t} \quad\left[\mathrm{R}^{2}=0.9999\right]$ 
Table 2. Statistical results obtained from the eight considered drying models at $2.0 \mathrm{~ms}^{-1}$ air velocity and varying drying temperatures.

\begin{tabular}{|c|c|c|c|c|c|c|c|c|c|}
\hline \multirow{2}{*}{$\begin{array}{l}\text { Model } \\
\text { name }\end{array}$} & \multicolumn{3}{|c|}{ Temp. $50^{\circ} \mathrm{C}$} & \multicolumn{3}{|c|}{ Temp. $55^{\circ} \mathrm{C}$} & \multicolumn{3}{|c|}{ Temp. $60^{\circ} \mathrm{C}$} \\
\hline & $R^{2}$ & $\chi^{2}$ & RMSE & $R^{2}$ & $\chi^{2}$ & RMSE & $R^{2}$ & $\chi^{2}$ & RMSE \\
\hline Lewis & 0.9987 & 2.5233 & 0.0242 & 0.9990 & 2.4218 & 0.0242 & 0.9996 & 2.4129 & 0.0218 \\
\hline Page & 0.9959 & 0.6723 & 0.00692 & 0.9961 & 0.6719 & 0.00653 & 0.9973 & 0.6231 & 0.00601 \\
\hline $\begin{array}{l}\text { Henderson } \\
\text { and Pabis }\end{array}$ & 0.9976 & 1.9273 & 0.0102 & 0.9981 & 1.9201 & 0.0100 & 0.9981 & 1.8407 & 0.00945 \\
\hline $\begin{array}{l}\text { Modified } \\
\text { Henderson } \\
\text { and Pabis }\end{array}$ & 0.9921 & 3.293 & 0.0197 & 0.9930 & 3.242 & 0.0181 & 0.9936 & 3.118 & 0.0174 \\
\hline Logarithmic & 0.9985 & 0.8763 & 0.00722 & 0.9986 & 0.8701 & 0.00711 & 0.9989 & 0.8614 & 0.00703 \\
\hline Two-term & 0.9955 & 0.7233 & 0.00726 & 0.9958 & 0.7015 & 0.00701 & 0.9962 & 0.6821 & 0.00631 \\
\hline Verma et al. & 0.9961 & 2.649 & 0.0273 & 0.9961 & 2.602 & 0.0220 & 0.9966 & 2.531 & 0.0171 \\
\hline $\begin{array}{l}\text { Midilli et } \\
\text { al. }\end{array}$ & 0.9993 & 0.2114 & 0.00438 & 0.9995 & 0.2106 & 0.00316 & 0.9997 & 0.1931 & 0.00281 \\
\hline \multirow{2}{*}{$\begin{array}{l}\text { Model } \\
\text { name }\end{array}$} & \multicolumn{6}{|c|}{ Temp. $65^{\circ} \mathrm{C}$} & \multicolumn{3}{|c|}{ Temp. $70^{\circ} \mathrm{C}$} \\
\hline & $R^{2}$ & $\chi^{2}$ & RMSE & & & & RMSE & $\boldsymbol{R}^{2}$ & $\chi^{2}$ \\
\hline Lewis & 0.9993 & 2.3704 & 0.02133 & & & & 0.9996 & 2.2014 & 0.0198 \\
\hline Page & 0.9980 & 0.5831 & 0.00601 & & & & 0.9987 & 0.5704 & 0.00549 \\
\hline $\begin{array}{l}\text { Henderson } \\
\text { and Pabis } \\
\text { Modified }\end{array}$ & 0.9984 & 1.8114 & 0.00945 & & & & 0.9989 & 1.7931 & 0.00724 \\
\hline $\begin{array}{l}\text { Henderson } \\
\text { and Pabis }\end{array}$ & 0.9941 & 2.504 & 0.0169 & & & & 0.9944 & 2.894 & 0.0149 \\
\hline Logarithmic & 0.9991 & 0.8401 & 0.00698 & & & & 0.9994 & 0.8277 & 0.00684 \\
\hline Two-term & 0.9966 & 0.6328 & 0.00622 & & & & 0.9969 & 0.6014 & 0.00619 \\
\hline Verma et al. & 0.9972 & 2.217 & 0.0136 & & & & 0.9974 & 2.109 & 0.0149 \\
\hline $\begin{array}{l}\text { Midilli et } \\
\text { al. }\end{array}$ & 0.9998 & 0.1783 & 0.00243 & & & & 0.9999 & 0.1136 & 0.00212 \\
\hline
\end{tabular}

Equation (15) was validated by plotting the values of the predicted moisture ratios against those of the experimental and is presented in Figure 2. The high coefficient of determination $\left(\mathrm{R}^{2}\right.$ $=0.9998$ ) which is close to unity, as well as the closeness of the points to the dotted lines indicate strong correlation or equality between the predicted and experimental values. Thus the suitability of the model to describe the drying behaviour of tomato slices in a convective hybrid solarelectric dryer. The behaviour of moisture ratio as a function of the drying time of tomato slices under the selected temperature levels at constant slice thickness is as shown in Figure 3.

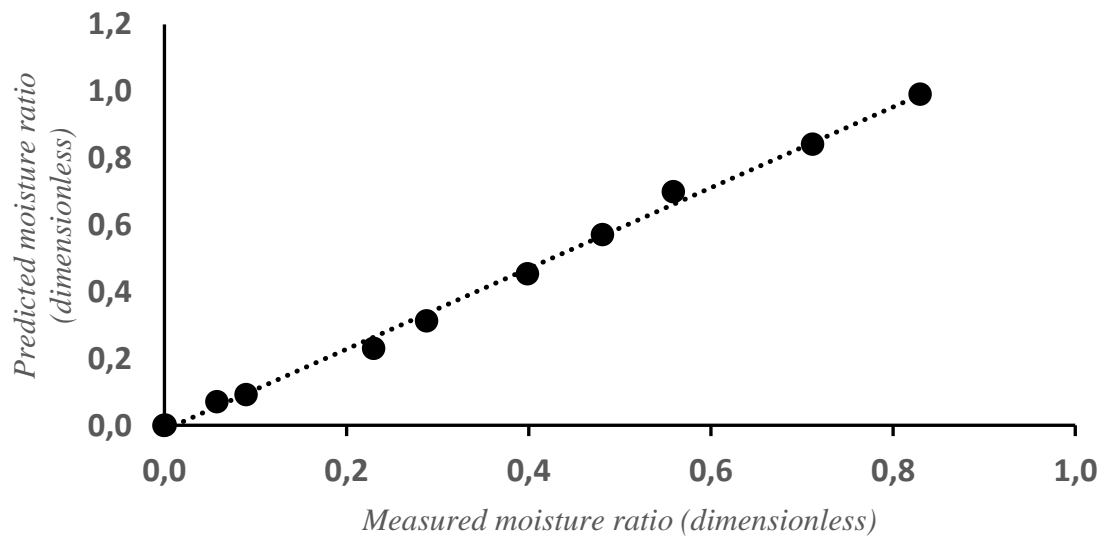

Figure 2. Predicted and experimental moisture ratio values for the Midilli model at $2.0 \mathrm{~ms}^{-1}$ and $70^{\circ} \mathrm{C}$ temperature. 


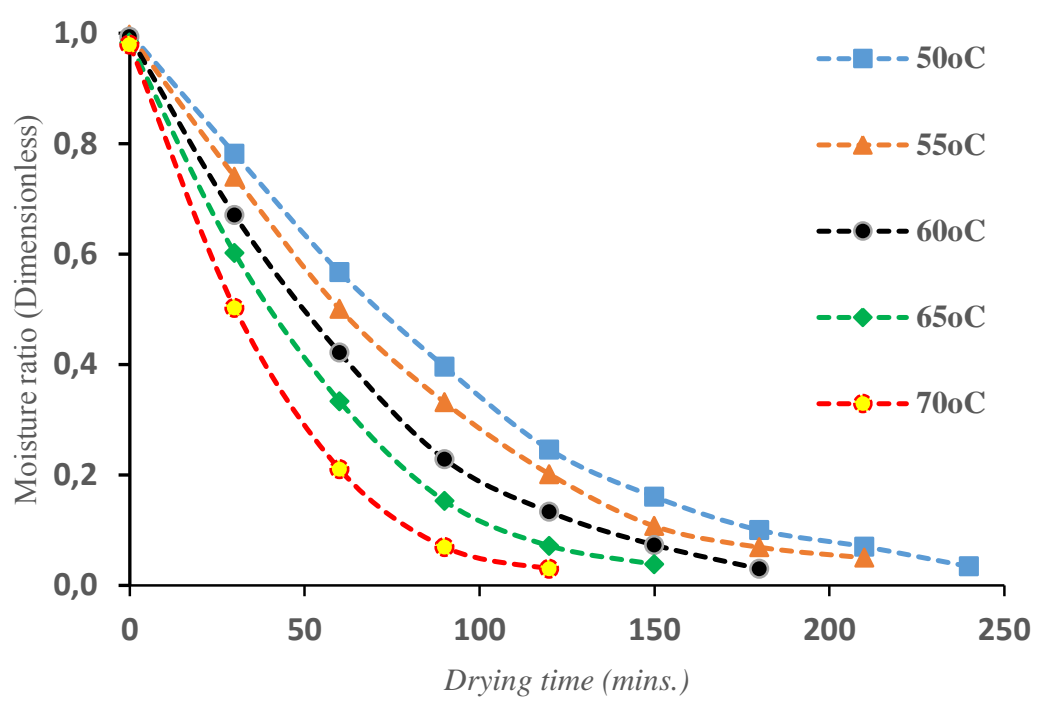

Figure 3. Drying curves of tomato slices described by Midilli et al. model at $2.0 \mathrm{~ms}^{-1}$ and varying temperature levels.

However, in the context of thin-layer drying models, [16] evaluated the drying of tomato samples and found that the Midilli et al. model was the most suitable to describe the drying process at temperature range of 20,40 and $60^{\circ} \mathrm{C}$ and at a constant air velocity of $2.0 \mathrm{~ms}^{-1}$. Similarly, [23] in drying of lemon grass leaves observed that Midilli et al. model was the best in describing the drying process at a temperature range of 30 to $60^{\circ} \mathrm{C}$. [24] found also that Midilli et $a l$. was adequate in describing the drying process of Cumari do Para pepper (Capsicum chinense Jacqui) at temperatures of 45,55 and $65^{\circ} \mathrm{C}$. All these corroborated with the present study.

Figure 3 illustrates that the higher the drying temperature, the shorter the drying time. This is as a result of increased kinetic energy of internal water molecules to diffuse and evaporate at higher rates from the interior and surface of the products to the ambient air respectively. This thus, increases the drying rate and reduces the drying time. This is in agreement with the findings of [25], in thin-layer drying of jujube fruits; [19] in drying of ginger slices; [6, 19] for okra slices; [1] for tomato slices; [5] in drying of carrot slices. There is a sharper decrease in the moisture ratio at the beginning of the drying process, which could probably be as a result of the high initial moisture content of the tomato samples ( $94.7 \%$ w.b), which increases moisture loss. According to [26], this occurs when the moisture content of the product sample exceeds $80 \%$ w.b., the internal resistance to water transport is usually lower than the external resistance to moisture removal from the sample surface to ambient/drying air, which marks the constant rate period. Owing to that, there is internal resistance to moisture diffusion and the mechanism for controlling the drying process is by diffusion. [26, 27] suggest that in this drying period, the decreasing rate of the product internal moisture corresponds to the internal water migration that make up the drying kinetics.

The drying constants, $\mathrm{K}_{\mathrm{d}}$ for the Midilli et al. model at different temperatures are given in Table 3. The natural logarithm of the drying constant, $\ln \left(\mathrm{K}_{\mathrm{d}}\right)$ is described as a function of the reciprocal of the absolute temperature, $\mathrm{T}_{\mathrm{a}}^{-1}$ as presented in Figure 4. $\mathrm{K}_{\mathrm{d}}$ increases in absolute values with temperature, due to greater heat transfer coefficient from the air to the product and, there is an increase in moisture diffusion to the product surface as a result of increased air velocity and temperature. The variations in the model parameters $(\mathrm{a}, \mathrm{n}$ and $\mathrm{b})$ are more related to mathematical fits than to a drying phenomenon, since Midilli is a semi-empirical model [26, 28]. 
Table 3. $K_{d}$-values of the fitted drying model for different temperatures.

\begin{tabular}{ccc}
\hline Temperature $\left({ }^{o} \boldsymbol{C}\right)$ & Midilli et al. model & $\boldsymbol{R}^{2}$ \\
\hline 50 & $M R_{\text {tomato }}=2.974 e^{\left(-0.3074 t^{1.202}\right)}+0.007 t$ & 0.9993 \\
55 & $M R_{\text {tomato }}=3.112 e^{\left(-0.4011 t^{1.196}\right)}+0.007 t$ & 0.9995 \\
60 & $M R_{\text {tomato }}=3.621 e^{\left(-0.49918 t^{1.22}\right)}+0.007 t$ & 0.9997 \\
65 & $M R_{\text {tomato }}=4.824 e^{\left(-0.6083 t^{1.282}\right)}+0.007 t$ & 0.9998 \\
70 & $M R_{\text {tomato }}=4.926 e^{\left(-0.8041 t^{1.322}\right)}+0.007 t$ & 0.9999 \\
\hline
\end{tabular}

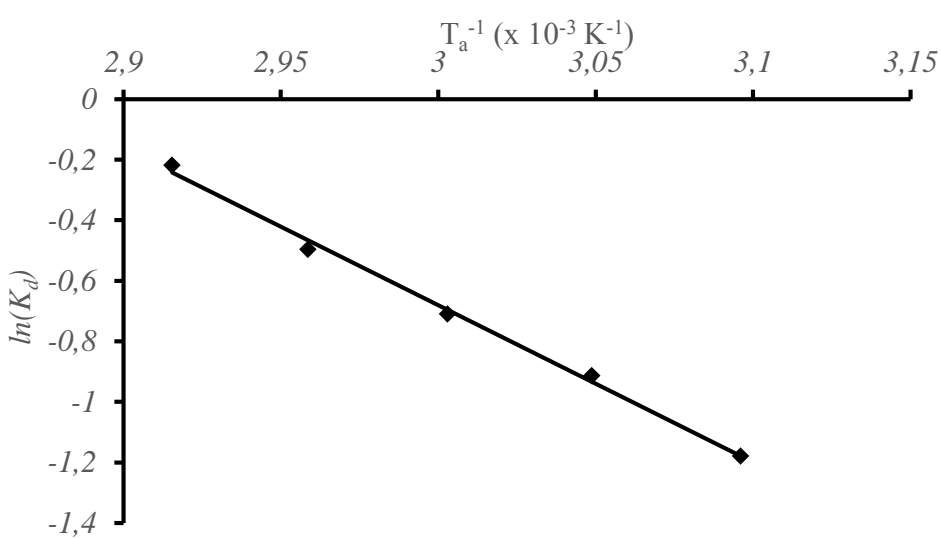

Figure 4. Arrhenius-type relationship between drying rate and absolute temperature of sliced tomato samples at constant air velocity and slice thickness.

The linear regression of the relationship between the logarithm of the drying constant and the inverse of the absolute temperature is expressed in Equation (15) as:

$\ln K_{d}=14.863-\frac{5.1815}{T_{a}} \quad\left[R^{2}=0.9967\right]$

The high $\mathrm{R}^{2}$-value (0.9967) indicates strong correlation between the parameters of the linear regression function. The moisture diffusivity, $\mathrm{D}_{\mathrm{e}}$ was calculated by substituting the values of Equation (7) into Equation (6b) and presented in Table 4. From Figure 4, the Arrhenius expression (Equation 8) can be written as:

$\mathrm{K}_{\mathrm{d}}=724328.28 \exp \left(\frac{38382.22}{8.3143 T_{a}}\right)$

Table 4. Effective moisture diffusivity $\left(D_{e}\right)$ of tomato slices in different drying temperature

\begin{tabular}{|c|c|c|c|c|c|}
\hline \multirow{2}{*}{$\begin{array}{l}\text { Air velocity } \\
\quad\left(m s^{-1}\right)\end{array}$} & \multicolumn{5}{|c|}{ Diffusion coefficient $\left(m^{2} s^{-1}\right)$} \\
\hline & $50^{\circ} \mathrm{C}$ & $55^{\circ} \mathrm{C}$ & $60^{\circ} \mathrm{C}$ & $65^{\circ} \mathrm{C}$ & $70^{\circ} \mathrm{C}$ \\
\hline 1.0 & $4.9541 \times 10^{-9}$ & $5.4729 \times 10^{-9}$ & $5.9156 \times 10^{-9}$ & $6.3817 \times 10^{-9}$ & $6.8153 \times 10^{-9}$ \\
\hline 1.5 & $5.1495 \times 10^{-9}$ & $5.8182 \times 10^{-9}$ & $6.2457 \times 10^{-9}$ & $6.5041 \times 10^{-9}$ & $7.1163 \times 10^{-9}$ \\
\hline 2.0 & $5.2364 \times 10^{-9}$ & $6.1922 \times 10^{-9}$ & $6.3343 \times 10^{-9}$ & $6.9932 \times 10^{-9}$ & $7.5726 \times 10^{-9}$ \\
\hline
\end{tabular}

The $\mathrm{D}_{\mathrm{e}}$ values fall within the reported range for vegetables and other food materials $[6,13$, $16,17,29,30,31]$. Moisture diffusivity was affected by the drying temperature and air velocity: $D_{e}$ values increased with increasing air temperature due to decrease in vapour pressure in the product matrix $[32,33]$. The minimum value of $\mathrm{D}_{\mathrm{e}}\left(4.9541 \times 10^{-9} \mathrm{~m}^{2} \mathrm{~s}^{-1}\right)$ was found at the minimum temperature, while at constant temperature values an increase in the air velocity increased $D_{e}$ values probably because at a low air velocity (say $0.1 \mathrm{~ms}^{-1}$ ), the drying air may had better contact with the sample surface but the rate of its heat and mass transfer was low as to necessitate greater absorption of moisture which results in decreased moisture diffusivity. 
Similar observations were reported by other researchers for carrot, berberis fruit, red chillies, apples, okra, ginger, tomato, bell pepper, melon, and field pumpkin $[1,2,13,14,15,17,19,30$, $34,35,36]$.

The slope of Figure 4 provides the relationship between $E_{a}$ and $R_{g}$, whereas the intersection with the $\ln \left(\mathrm{K}_{\mathrm{d}}\right)$-axis indicates the $\mathrm{A}_{\mathrm{o}}$-values. Table 5 shows that $\mathrm{E}_{\mathrm{a}}$-values and their corresponding $\mathrm{R}^{2}$ and the pre-exponential factor values of the sliced tomato samples are within the range of $\mathrm{E}_{\mathrm{a}}$-values for food materials $\left(12.7\right.$ to $\left.110 \mathrm{kJmol}^{-1}\right)$ as reported by $[1,5,14,19]$.

Table 5. Activation energy, pre-exponential factor and $R^{2}$-values of tomato slices at varying air velocities.

\begin{tabular}{cccc}
\hline Air velocity $\left(\mathbf{m s}^{\mathbf{- 1}}\right)$ & $\mathbf{E}_{\mathbf{a}}\left(\mathbf{k J m o l}{ }^{-\mathbf{1}}\right)$ & $\mathbf{R}^{\mathbf{2}}$ & $\mathbf{A}_{\mathbf{O}} \mathbf{x} \mathbf{1 0}^{\mathbf{- 3}}\left(\mathbf{m}^{\mathbf{2}} \mathbf{s}^{\mathbf{- 1}}\right)$ \\
\hline 1.0 & 40.96 & 0.9692 & 8.62 \\
1.5 & 39.21 & 0.9703 & 7.07 \\
2.0 & 37.86 & 0.9734 & 6.31 \\
Mean & $\mathbf{3 9 . 3 4 2}$ & $\mathbf{0 . 9 7 1}$ & $\mathbf{7 . 3 3 3}$ \\
\hline
\end{tabular}

From Table 5, the activation energy, $\mathrm{E}_{\mathrm{a}}$ of sliced tomato samples decrease with increasing air velocity. The $E_{a}$-values obtained from this present study are within the range (33.33 to 43.23 $\mathrm{kJmol}^{-1}$ ) obtained by [16] for similar air velocity and temperature ranges. The high $\mathrm{E}_{\mathrm{a}}$-values were as a result of the relatively small amount of water removed by the thermal energy of the drying air. Activation energy is the energy barrier that must be overcome in order to initiate moisture diffusion. By increasing the temperature and drying rate (air flow), this energy barrier can be easily overcome but there should be a compromise between drying temperature and acceptable product quality [13]. Increasing the air velocity (at increased temperature) speeds up the rate of surface moisture evaporation, and most importantly increases the heat transfer rate which in turn increases the kinetic energy of the internal moisture for rapid collision, hence reduced activation energy. The mean $\mathrm{E}_{\mathrm{a}}$-value obtained from Figure 4 at varying air velocities was $38.38 \mathrm{kJmol}^{-1}$. Correa et al. [37] corroborated that the lower the $\mathrm{E}_{\mathrm{a}}$, the higher will be the water diffusivity in the product sample, i.e., the lower will be the energy necessary for physical transformation to occur, which refers to the transformation of liquid free water to vapour (drying). Similar observations were reported in the works of [6, 13, 16, 17] for sliced food materials.

Thermodynamically, $\mathrm{E}_{\mathrm{a}}$ is defined as the ease with which water molecules surpass the energy barrier during internal moisture diffusion [26, 38]. The thermodynamic properties of sliced tomato drying were determined using Equations (11) to (13), and presented in Table 6.

Table 6. Thermodynamic properties of dried sliced tomato.

\begin{tabular}{|c|c|c|c|}
\hline Temperature $\left({ }^{\circ} \mathrm{C}\right)$ & $\Delta H\left(\mathrm{Jmol}^{-1}\right)$ & $\Delta S\left(\mathrm{Jmol}^{-1}\right)$ & $\Delta G\left(\mathrm{Jmol}^{-1}\right)$ \\
\hline 50 & 35695.45 & -64.14 & 14968.61 \\
\hline 55 & 35653.88 & -64.05 & 14635.87 \\
\hline 60 & 35612.31 & -63.89 & 14327.36 \\
\hline 65 & 35570.74 & -63.77 & 14006.34 \\
\hline 70 & 35529.17 & -63.65 & 13687.67 \\
\hline
\end{tabular}

Enthalpy decreased with increasing temperature, implying a lower energy requirement for drying of sliced tomato at higher drying temperatures. The positive values of the enthalpy, $\Delta \mathrm{H}$ indicate that the drying process is an endothermic reaction, which requires addition or supply of energy in the form of heat for the physico-chemical transformations to occur. As the temperature of the drying chamber increased, entropy of the system also decreased; indicating increase in the order of the system, which is entropically unfavourable [26].

Some researchers $[26,39]$ suggest that a substance such as water can have only entropy if the degrees of freedom of the movement of translation or rotation are lost. Gibbs free energy (free enthalpy) is a thermodynamic potential of a system that can be considered as a measurement of maximum reversible work performed by a thermodynamic system in the process of moisture adsorption or desorption (i.e., moisture gain or loss) [26, 40]. According to Costa et al. [26], Gibbs energy provides clearer understanding of the thermodynamic driving forces that affect reactions. 
However, in the drying of tomato slices, the effect of enthalpy was evident; which decreased with increasing drying temperatures, with its maximum $\left(14968.61 \mathrm{kJmol}^{-1}\right)$ corresponding with the minimum temperature $\left(50^{\circ} \mathrm{C}\right)$ and its positive values indicating endergonic reactions: supply of heat energy from the ambient environment - drying chamber, in which the sliced samples are kept for heat and mass reactions to occur.

\section{CONCLUSION}

Thin-layer mathematical modeling and determination of thermodynamic properties of sliced tomato samples during hot air drying in a hybrid solar-electric dryer were investigated at five different drying temperatures $\left(50,55,60,65\right.$ and $\left.70^{\circ} \mathrm{C}\right)$, three different air velocities $(1.0,1.5$ and $\left.2.0 \mathrm{~ms}^{-1}\right)$, and at a constant slice thickness $(10 \mathrm{~mm})$. The following results were obtained as summarized below:

1. According to statistical analyses applied to the eight selected models, the Midilli et al. model gave the best fit to the experimental data of drying of tomato slices with the highest value of R2 (0.9999), lowest value of $\chi^{2}=0.1136$, and lowest value of RMSE $=$ 0.0212 at $70 \mathrm{oC}$ temperature and $2.0 \mathrm{~ms}-1$ air velocity.

2. The model equation is expressedas: $\mathrm{MR}_{\text {tomato }}=4.926 \mathrm{e}^{\left(-0.8041 \mathrm{t}^{1.322}\right)}+0.027 \mathrm{t}$

3. The drying constant increased with increases in drying temperature. Temperature and air velocity influenced both moisture diffusivity and activation energy. The value of moisture diffusivity increased with increase in temperature and air velocity. The highest effective moisture diffusivity was observed at air velocity of $2.0 \mathrm{~ms}-1$ and temperature of $70 \mathrm{oC}$, whereas it was lowest at air velocity of $1.0 \mathrm{~ms}-1$ and temperature of $50 \mathrm{oC}$.

4. The activation energy of sliced tomato decreased with air velocity. The mean activation energy required to drying $1 \mathrm{~kg}$ batch of $10 \mathrm{~mm}$ sliced tomato samples in a hybrid solarelectric dryer is $39.34 \mathrm{kJmol}-1$.

5. The effects of different drying temperatures on the thermodynamic properties of dried tomato slices such as enthalpy, entropy and, Gibbs free energy were studied. Enthalpy and Gibbs free energy decreased with increase in temperature, as well as entropy which exothermically decreased with increasing temperature.

Further studies on optimization of the drying process and determination of thermodynamic properties of different varieties of sliced fruits and vegetables at varying air velocities, sample thicknesses and drying temperatures using different drying systems are recommended. Experimental investigation on the heat and mass transfer parameters as well as the thermal utilization efficiency and dried product quality assessment of various species of sliced vegetables, roots and tuber crops using any solar-assisted hybrid dryer with a heat recovery unit is of great importance for future work.

\section{REFERENCES}

[1] Abano, E.E.; Ma, H.; Qu, W. 2011. Influence of air temperature on the drying kinetics and quality of tomato slices. Food Processing and Technology, 2(5), pp.1-9.

[2] Dianda, B.; Ousmane, M.; Kam, S.; Ky, T; Bathiebo, D.J. 2015. Experimental study of the kinetics and shrinkage of tomato slices in convective drying. African Journal of Food Science, 9(5), pp. 262-271.

[3] Mu'azu, K.; Bugaje, I.M.; Mohammed, I.A. Performance evaluation of forced airconvection vegetable drying system. Journal of Basic and Applied Scientific Research 2012, 2(3), pp. 2562-2568.

[4] Idah, P.A.; Obajemihi, O.I.; Adeboye, O.A.; Olaniyan, A.M. 2014. Assessment of osmotic pre-drying treatment on drying rates of fresh tomato fruits. Nigerian Journal of Technological Development, 11(1), pp. 22 - 26. 
[5] Doymaz, I. 2004a. Convective air drying characteristics for thin-layer carrots. Journal of Food Engineering, 61(3), pp.359-364.

[6] Doymaz, I. 2004b. Drying characteristics and kinetics of okra. 69(2005), pp.275-279.

[7] Darvish, H. 2012. Energy consumption and mathematical modeling of microwave drying of potato slices. Agricultural Engineering International, CIGR Journal, 14(1), pp. 94- 102.

[8] Darvishi, H.; Asi, R.A.; Asghari, A.; Najafi, G.; Gazori, H.A. 2013. Mathematical modeling, moisture diffusion, energy consumption and efficiency of thin-layer drying of potato slices. Journal of Food Process Technology, 4 (3), pp. 215 - 229.

[9] Sahari, Y.; Driscoll, R. H. 2013. Thin layer drying of agricultural products: a review. Malaysian Postgraduate Conference, pp., 8-21.

[10] Costa, C.F.; Correa, P.C.; Vanegas, J.D.B. 2016. Matematical modeling and determination of thermodynamic properties of jabuticaba peel during the drying process, Revista Brasileira de Engenharia Agricola e Ambiental, 20(6), pp.576-580.

[11] Jideani, V.A.; Mpotokwana, S.M. 2009. Modeling of water absorption of Botswana Bambara varieties using Peleg's equation, Journal of Food Engineering, 92, pp.182-188.

[12] Oliveira, D.E.C.; Resende, O.; Chaves, T.H.; Souza, K.A.; Smaniotto, T.A.S. 2014. Proriedades termodinamicas das sementes de pinhaomanso. Bioscience Journal, 30, pp. $147-157$.

[13] Afolabi, T.J.; Agarry, S.E. 2014. Thin layer drying kinetics and modelling of okra (Abelmoschus Esculentus L.) slices under natural and forced convective air drying. Food Science and Quality Management, 28, pp.30-44.

[14] Sadin, R.; Chegini, G.; Khodadadi, M. 2017. Drying characteristics and modeling of tomato thin layer drying in combined infra-red hot air dryer. Agricultural Engineering International, CIGR E-Journal, 19(1), pp.150 - 157.

[15] Aghbashlo, M.; Kianmehr, M.H.; Samimi-Akhijahani, H. 2008. Influence of drying conditions on the effective moisture diffusivity, energy of activation and energy consumption during the thin-layer drying of beriberi fruit (Berberidaceae). Energy Conversion and Management, 49, pp.2865-2871.

[16] Taheri-Garavand, A.; Rafieea, S.; Keyhania, A. 2011a. Mathematical modeling of thin layer drying kinetics of tomato influence of air dryer conditions. International Transaction Journal of Engineering, Management and Applied Sciences and Technologies, 2(2), pp.147-160.

[17] Taheri-Garavand, A.; Rafieea, S.; Keyhania, A. 2011b. Study on effective moisture diffusivity, activation energy and mathematical modeling of thin layer drying kinetics of bell pepper. Australian Journal of Crop Science, 5(2), pp.128-131.

[18] Abbaszadeh, A.; Motevali, A.; Ghobadian, B. 2012. Effect of air velocity and temperature on energy and effective moisture diffusivity for Russian Olive (Elaeagnusan gastifolial L.) in thin layer drying. Iran Journal of Chemical Engineering, 31(1), pp.75-79.

[19] Afolabi, T.J.; Akintunde, T.Y.; Oyelade, O.J. 2014. Influence of drying conditions on the effective moisture diffusivity and energy requirements of ginger slices. Journal of Food Research, 3(5), pp.103-112.

[20] Zielinska, M.; Markowski, M. 2010. Air drying characteristics and moisture diffusivity of carrots. Chemical Engineering and Processing, No 49: pp.212-218.

[21] Association of Official Agricultural Chemists, (AOAC) Int. Maryland, USA, 2005, P.4.

[22] Koyuncu, T.; Tosun, I.; Pinar, Y. 2007. Drying characteristics and heat energy requirement of cornelian cherry fruits (Cornus mas L.). J. of Food Eng., 78(4), pp. $735-739$. 
[23] Martinazzo, A. P.; Corrêa, P. C.; Resende, O.; Melo, E. De, C. 2007. Análise e descrição matemática da cinética de secagem de folhas de capim-limão. Revista Brasileira de Engenharia Agrícola e Ambiental, 11, 301-306. http://dx.doi.org/10.1590/ S141543662007000300009

[24] Reis, R. C.; Barbosa, L. S.; Lima, M. de L.; Reis, J. de S.; Devilla, I. A.; Ascheri, D. P. R. 2011. Modelagem matemática da secagem da pimenta Cumari do Pará. Revista Brasileira de Engenharia Agrícola e Ambiental, 15. pp.347-353.

[25] Motevali, A.; Abbaszadeh, A.; Minaei, S.; khostaghaza, M.H.; Ghobadian, B. 2012. Effective moisture diffusivity, activation energy and energy consumption in thin-layer drying of jujube (Zizyphus jujube Mill). J.of Agr. Science and Technology, 14, pp.523532.

[26] Costa, L. M.; Resende, O.; Gonçalves, D. N.; Oliveira, D. E. C. de. 2015. Modelagem matemática da secagem de frutos de crambe em camada delgada. Bioscience Journal, 31, pp. 392-403.

[27] Oliveira, R. A. de; Oliveira, W. P. de; Park, K. J. 2006. Determinação da difusividade efetiva de raiz de chicória. Engenharia Agrícola, 26,181-189.

[28] Midilli, A.; Kucuk, H.; Yapar, Z. 2002. A new model for single-layer drying. Drying Technology, 20, pp. 150-160.

[29] Doymaz, I. 2005. Drying Behaviour of Green Beans. Journal of Food Engineering, 69, pp. 161-165.

[30] Aghbashlo, M.; Kianmehr, M.H.; Khani, S.; Ghasemi, M. 2009. Mathematical modelling of thin-layer drying of carrot, International Agro physics, 23, 313-317.

[31] Honore, O.K.; Francois, Z.; Raguilignaba, S. 2014. Characterization of okra convective drying, influence of maturity. Food and Nutrition Sciences, 5, pp. $590-597$.

[32] Nwakuba, N.R.; Asoegwu, S.N; Nwaigwe, K.N. 2016a. Energy consumption of agricultural dryers: an overview. Agricultural Engineering International: CIGR Journal, 18(4), pp. 119-132.

[33] Nwakuba, N.R.; Asoegwu, S.N.; Nwaigwe, K.N. 2016b. Energy requirements for drying of sliced agricultural products: a review. Agricultural Engineering International: CIGR Journal, 18(2), pp. 144-155.

[34] Meisami-asl, E.; Rafiee, S.; Keyhani, A.; Tabatabaeefar, A. 2010. Drying of apple slices and effect on moisture diffusivity and activation energy. Plant Omics Journal, 3(3), pp. 97-102.

[35] Azadbakht, M.; Darvishi, H.; Rezaeiasl, A.; Asghari, A. 2012. Thin layer drying characteristics and modelling of melon slices (Cucumismelo). Journal of Agricultural Technology, 8(6), pp. 1867-1880.

[36] Olurin, T.O.; Adelekan, A.O.; Olosunde, W.A. 2012. Mathematical modelling of drying characteristics of balanced field pumpkin (Cucurbita pepo L) slices. Agricultural Engineering International: CIGR E-Journal, 14(4), pp. 246-254.

[37] Corrêa, G. C.; Oliveira, G. H. H.; Botelho, F. M.; Goneli, A. L. D.; Carvalho, F. M. 2018. Modelagem matemática e determinação das propriedades termodinâmicas do café (Coffea arabica L.) durante o processo de secagem. Revista Ceres 2010, 57, 595-601. http:// dx.doi.org/10.1590/S0034-737X2010000500005 (accessed January 15, 2018).

[38] Resende, O.; Ferreira, L. U.; Almeida, D. P. 2010. Modelagem matemática para descrição da cinética de secagem do feijão azuki (Vigna angularis). Revista Brasileira de Produtos Agroindustriais, 12, 171-178. http://dx.doi.org/10.15871/1517-8595/rbpa.

[39] Dannenberg, F.; Kessler, H. 1988. Reaction kinetics of the denaturation of whey proteins in milk. Journal of Food Science, 53, pp. 258-263.

[40] Kaleemullah, S.; Kailappan, R. 2007. Monolayer moisture, free energy change and fractionation of bound water of red chillies. Journal of Stored Products Research, 43, pp. 104-110. 


\title{
MODELI I TERMODINMAČKE OSOBINE TANKIH KRIŠKI PARADAJZA SUŠENOG VRELIM VAZDUHOM
}

\author{
Nnaemeka Nwakuba ${ }^{1}$, Osita Chukwuezie $^{2}$, Sabbas Asoegwu ${ }^{3}$, \\ Godfrey Nwandikom ${ }^{3}$, Ngozi Okereke ${ }^{3}$
}

${ }^{\text {I}}$ Odsek za poljoprivredno inžinjerstvo i resurse, Michael Okpara Poljoprivredni Univerzitet, Umudike, P.M.B. 7267 Umuahia, Abia, Nigeria.

${ }^{2}$ Odsek za poljoprivredno inžinjerstvo i životnu sredinu, Imo State Polytechnika, Umuagwo, P.M.B. 1472, Imo, Nigeria.

${ }^{3}$ Odsek za poljoprivredno inžinjerstvo i resurse, Federalni Univerzitet za tehnologiju, P.M.B. 1526 Owerri, Imo, Nigeria.

$\diamond$

Sažetak: Prikazana je kinetika sušenja i određivanje termodinamičkih osobina uzoraka narezanog paradajza tokom sušenja toplim vazduhom u solarnoj sušari. $1 \mathrm{~kg}$ svežih uzoraka paradajza su rezane na debljinu $10 \mathrm{~mm}$ i sušene na različitim brzinama vazduha $(1,0,1,5$ i 2,0 $\left.\mathrm{ms}^{-1}\right)$ i temperaturama $\left(50,55,60,65\right.$ i $\left.70{ }^{\circ} \mathrm{C}\right)$ hibridnim načinom sušenja. Da bi se izabrao najbolji model sušenja, urađeno je 8 tanko-slojnih matematičkih modela sa eksperimentalnim podacima. Visoke vrednosti koeficijenta determinacije, R2 i male vrednosti smanjene sume kvadrata greške (SSE) i kvadratne greške (RMSE) ukazuju da su Midilli i sar. model adekvatno opisali proces sušenja narezanog paradajza, sa najvišim R2 (0.9999), najnižim SSE (0.1136) i najnižom vrednosti RMSE (0.0212) pri temperaturi od $70^{\circ} \mathrm{C}$ i brzinom vazduha $2.0 \mathrm{~ms}^{-1}$. Arrenius model predstavlja konstantu sušenja kao funkciju temperature. Efikasna difuzivnost vlage se pove ava sa pove anjem temperature i brzine vazduha; sa najve om vrednoš u dobijenom brzinom vazduha od $2,0 \mathrm{~ms}^{-1} \mathrm{i}$ temperaturom od $70^{\circ} \mathrm{C}$, dok je bila najmanja brzina vazduha od $1,0 \mathrm{~ms}^{-1}$ i temperatura od $50^{\circ} \mathrm{C}$. Srednja energija aktivacije koja je potrebna za sušenje $1 \mathrm{~kg}$ šarže od $10 \mathrm{~mm}$ rezanih uzoraka paradajza bila je $39,34 \mathrm{kJmol}^{-1}$. Utvrđeno je da se smanjuju vrednosti slobodne energije Enthalpy i Gibbs sa pove anom temperaturom sušenja, kao i entropijom koja je takođe ekzotermno smanjena sa temperaturom. Navedene su preporuke za dalje istraživanje.

Ključne reči: termodinamička osobine, kinetika sušenja, rezanci paradajza, desorpcija vode, energija aktivacije.

Prijavljen:

Submitted: Ispravljen:

Revised:

Prihva en:

Accepted:

\section{03. 2018.}

01.04 .218

04.04.2018 